\title{
The Effect of Mudharabah Financing and Musyarakah Financing on Profitability Ratios at PT. Bank BRI Syariah TBK Period 2012-2018
}

\author{
Norma Sari ${ }^{1}$, Budi Gautama Siregar ${ }^{2}$, Hamni Fadilah Nasution ${ }^{3}$, Damri Batubara ${ }^{4}$ \\ ${ }^{1}$ IAIN Padangsidimpuan (Perbankan Syariah, FEBI, IAIN Padangsidimpuan) \\ ${ }^{2}$ IAIN Padangsidimpuan (Perbankan Syariah, FEBI, IAIN Padangsidimpuan) \\ ${ }^{3}$ IAIN Padangsidimpuan (Perbankan Syariah, FEBI, IAIN Padangsidimpuan) \\ ${ }^{4}$ IAIN Padangsidimpuan (Perbankan Syariah, FEBI, IAIN Padangsidimpuan) \\ nurhidaya@gmail.com¹ ${ }^{1}$, budigautama@iain-padangsidimpuan.ac.id², hamnifadillah@iain- \\ padangsidimpuan.ac.id ${ }^{3}$, damribatubara@iain-padangsidimpuan.ac.id ${ }^{4}$
}

\begin{abstract}
ABSTRAK
Latar belakang masalah dalam penelitian ini adalah pembiayaan mudharabah dan pembiayaan musyarakah mengalami fluktuasi tidak di ikuti Return On Asset (ROA), yang sesuai dengan teori pembiayaan meningkat maka Return On Asset (ROA) sebaliknya. Rumusan dalam penelitian ini adalah apakah terdapat pengaruh pembiayaan mudharabah dan pembiayan musyarakah terhadap Return On Asset (ROA) pada PT. Bank BRI Syariah TBK secara parsial maupun simultan. Penelitian ini merupakan penelitian kuantitatif deskriptif, sampel yang digunakan sebanyak 36 sampel dengan desain purposive sampling, data diperoleh melalui situs www.OJK.go.id pengujian dalam penelitian ini adalah dengan menggunakan program computer SPSS Versi 23. Hasil penelitian menunjukkan bahwa secara parsial terdapat pengaruh pembiayaan mudharabah terhadap Return On Asset (ROA) pada PT. Bank BRI Syariah Tbk, dan Pembiayaan musyarakah menunjukkan bahwa secara parsial pembiayaan musyarakah berpengaruh terhadap Return On Asset (ROA) ) pada PT. Bank BRI Syariah Tbk. Dengan hasil uji F berpengaruh secara taraf sig. Sehingga hipotesis (Ha3) diterima. Jadi dapat disimpulkan bahwa secara simultan ada pengaruh antara pembiayaan mudharabah dan pembiayaan musyarakah terhadap Return On Asset (ROA). Sedangkan uji determinasi R2square varibel 33 persen sedangkan sisanya 67 persen yang dipengaruhi faktor lain yang tidak dimasukkan dalam penelitianian ini.
\end{abstract}

Kata Kunci: Religiusitas, Pelayanan, Promosi, Minat

\begin{abstract}
The background problem in this research is mudharabah financing and musyarakah financing experiencing fluctuations that are not followed by Return On Assets (ROA), which in accordance with the theory of increased financing, the Return On Assets (ROA) vice versa. The formula in this research is whether there is an influence of mudharabah financing and musyarakah financing on Return On Assets (ROA) at PT. Bank BRI Syariah TBK partially or simultaneously. This research is a quantitative descriptive study, the sample used as many as 36 samples with a purposive sampling design, data obtained through the website www.OJK.go.id testing in this study is to use the SPSS computer program Version 23. The results showed that partially there was the influence of mudharabah financing on Return On Assets (ROA) at PT. Bank BRI Syariah Tbk, and Musharaka financing shows that musyarakah financing partially influences Return On Assets (ROA) at PT. Bank BRI Syariah Tbk. With the results of the $F$ test influential in the level of sig. So the hypothesis (Ha3) is accepted. So it can be concluded that simultaneously there is an influence between mudharabah financing and musyarakah financing on Return On Assets (ROA). While the R2square determination test is 33 percent while the remaining 67 percent is influenced by other factors not included in this study.
\end{abstract}

Keywords: Religiosity, Service, Promotion, Interest 


\section{Journal of Sharia Banking}

\section{A. PENDAHULUAN}

Perbankan adalah satu lembaga yang melaksanakan tiga fungsi utama, yaitu (1) menerima simpanan uang, (2) meminjamkan uang, dan (3) memberikan jasa pengiriman uang. Di dalam sejarah perekonomian kaum muslimin, pembiayaan yang dilakukan dengan akad yang sesuai syariah telah menjadi bagian dari tradisi umat Islam sejak zaman Rasulullah SAW. Pedagang mampu memberikan manfaat yang besar baik bagi masyarakat serta bagi pemerintah.Beberapa manfaat dengan adanya pedagang seperti peningkatan pendapatan masyarakat, penyerapan tenaga kerja yang secara otomatis mengurangi tingkat pengangguran dan membantu dalam pertumbuhan perekonomian di Indonesia.

Kondisi para pedagang yang berada di Pasar baru panyabungan itu sendiri tidak jauh berbeda dengan kondisi para pedagang pada umumnya. Para pedagang di Pasar baru Panyabungan juga mengalami beberapa permasalahan lainnya dalam menjalankan usahanya. Dalam hal ini fenomena yang terjadi adalah minimnya minat pedagang yang menabung di bank syariah. Jumlah pedagang di Pasar Baru Panyabungan cukup banyak dengan mayoritas muslim, dengan latar belakang pendidikan yang berbeda-beda dan penghasilan yang berbeda-beda pula. Berdasarkan data yang diperoleh dari pengamatan sementara di lokasi Pasar Baru Panyabungan dapat diketahui bahwa jumlah pedagangnya sebanyak 1.441 pedagang.

Adapun beberapa faktor yang mempengaruhi minat nasabah dalam menabung di bank syariah adalah religiusitas, pelayanan dan promosi. Menurut Abdurrahman Saleh "minat merupakan suatu kecenderungan untuk memberikan perhatian dan bertindak terhadap orang, aktivitas atau situasi yang menjadi objek dari minat tersebut dengan di sertai perasaan senang". Istilah religiusitas (religiosity) berasal dari bahasa ingris "religion" yang berarti agama, kemudian menjadi kata sifat "religious" yang berarti agamis atau saleh. "religi" berarti kepercayaan kepada adanya kekuatan di atas manusia. "religiusitas" adalah pengabdian terhadap agama atau kesalihan. Pelayanan pada dasarnya adalah kegiatan yang ditawarkan kepada konsumen atau nasabah yang dilayanani, yang bersifat tidak berwujud dan tidak dapat dimiliki. Promosi dilakukan dengan tujuan menginformasikan dan mempengaruhi pasar akan produk bank melalui kegiatan-kegiatan periklanan, personal selling, publisitas dan sebagainya. Dengan kegiatan tersebut bank dapat membujuk nasabah agar tetap loyal memakai produk bank bahkan dapat ditingkatkan loyalitasnya sehingga enggan untuk meninggalkan produk bank.

\section{B. METODE}

Lokasi penelitian dilakukan di Pasar Baru Panyabungan. Jenis penelitian yang digunakan 
adalah kuantitatif deskriptif yang bermaksud menggambarkan fenomena pada objek penelitian apa adanya dan pengambilan kesimpulan didasarkan pada angka-angka hasil analisis statistik. Populasi dalam penelitian ini adalah pedagang di Pasar Baru Panyabungan yang menabung di bank syariah. Dimana jumlah populasinya adalah 508 pedagang. Yang didapatkan dari observasi awal. Sampel yang diambil dari penelitian ini adalah 84 sampel.Metode yang digunakan untuk menghitung besarnya jumlah sampel adalah rumus Slovin. Sumber data dalam penelitian ini adalah data primer, yaitu pedagang di pasar baru Panyabungan yang menabung di bank syariah. Teknik pengumpulan data yang dilakukan dalam penelitian ini menggunakan instrumen wawancara dan angket.

Variabel independen yang digunakan adalah religiusitas, pelayanan dan promosi. Sedangkan variabel dependen adalah minat menabung. Data yang sudah terkumpul selanjutnya dikuantitatifkan kemudian dilakukan analisis menggunakan aplikasi program Statistical Product and Service Solution (SPSS) versi 23.

\section{HASIL DAN PEMBAHASAN}

1. Uji Validitas

Uji Validitas Religiusitas

\begin{tabular}{|c|c|c|c|}
\hline Religiusitas_4 & 0,475 & \multirow{8}{*}{$\begin{array}{l}\text { signifikan } \quad 5 \% \\
\text { sehingga } \\
\text { diperoleh } \\
r_{\text {tabel }}= \\
0,2159\end{array}$} & Valid \\
\hline Religiusitas_5 & 0,437 & & Valid \\
\hline Religiusitas_6 & 0,589 & & Valid \\
\hline Religiusitas_7 & 0,572 & & Valid \\
\hline Religiusitas_8 & 0,545 & & Valid \\
\hline Religiusitas_9 & 0,622 & & Valid \\
\hline Religiusitas_10 & 0,624 & & Valid \\
\hline Religiusitas 11 & 0,594 & & Valid \\
\hline
\end{tabular}

Sumber: Hasil Output SPSS Versi 23

Berdasarkan uji validitas di atas menunjukkan bahwa nilai $r_{\text {hitung }}$ dari item pernyataan religius 2 sampai dengan 11 menunjukkan angka lebih besar dari $r_{\text {tabel }}$ yaitu 0,2159 . Hal tersebut menunjukkan bahwa item pernyataan religius 2 sampai dengan 11 dinyatakan valid, kecuali pernyataan religiusitas 1 yang menunjukkan angka $r_{\text {hitung }}<r_{\text {tabel }}$ yaitu dibawah 0,2159. Hal tersebut menunjukkan bahwa item pernyataan religiusitas 1 tidak valid.

Uji Validitas Pelayanan

\begin{tabular}{|c|c|c|c|}
\hline $\begin{array}{c}\text { Item } \\
\text { Pernyataan }\end{array}$ & $r_{\text {hitung }}$ & $r_{\text {tabel }}$ & Keterangan \\
\hline Pelayanan_1 & 0,390 & \multirow{11}{*}{$\begin{array}{l}\text { Instrument } \\
\text { valid jika } \\
r_{\text {hitung }}>r_{\text {tabel }} \\
\text { dengan } \quad d f= \\
\text { pada taraf } \\
\text { signifikan } 5 \% \\
\text { sehingga } \\
\text { diperoleh } \\
r_{\text {tabel }}=0,2159\end{array}$} & Valid \\
\hline Pelayanan_2 & 0,713 & & Valid \\
\hline Pelayanan_3 & 0,434 & & Valid \\
\hline Pelayanan_4 & 0,396 & & Valid \\
\hline Pelayanan_5 & 0,542 & & Valid \\
\hline Pelayanan_6 & 0,549 & & Valid \\
\hline Pelayanan_7 & 0,573 & & Valid \\
\hline Pelayanan_8 & 0,500 & & Valid \\
\hline Pelayanan_9 & 0,575 & & Valid \\
\hline Pelayanan_10 & 0,506 & & Valid \\
\hline Pelayanan_11 & 0,494 & & Valid \\
\hline
\end{tabular}

Sumber: Hasil Output SPSS Versi 23

Berdasarkan hasil uji validitas di atas menunjukkan bahwa nilai rhitung dari masing- 
Norma Sari ${ }^{1}$, Budi GautamaSiregar ${ }^{2}$, Hamni Fadilah Nasution ${ }^{3}$, Damri Batubara 4

Uji Validitas Promosi

\begin{tabular}{|c|c|c|c|}
\hline $\begin{array}{c}\text { Item } \\
\text { pernyataan }\end{array}$ & $r_{\text {hitung }}$ & $r_{\text {tabel }}$ & Keterangan \\
\hline promosi_1 & 0,323 & \multirow{11}{*}{$\begin{array}{c}\text { Instrument } \\
\text { valid jika } \\
r_{\text {hitung }}>r_{\text {tabel }} \\
\text { dengan } \mathrm{df}= \\
\text { pada taraf } \\
\text { signifikan 5\% } \\
\text { sehingga } \\
\text { diperoleh } \\
r_{\text {tabel }}=0,2159\end{array}$} & Valid \\
\hline promosi_2 & 0,456 & & Valid \\
\hline promosi_3 & 0,322 & & Valid \\
\hline promosi_4 & 0,490 & & Valid \\
\hline promosi_5 & 0,514 & & Valid \\
\hline promosi_6 & 0,237 & & Valid \\
\hline promosi_7 & 0,396 & & Valid \\
\hline promosi_8 & 0,237 & & Valid \\
\hline promosi_9 & 0,425 & & Valid \\
\hline promosi_10 & 0,354 & & Valid \\
\hline promosi_11 & 0,202 & & Valid \\
\hline
\end{tabular}

Sumber: Hasil Output SPSS Versi 23

Berdasarkan hasil uji validitas promosi di atas menunjukkan bahwa nilai rhitung dari masing-masing item pernyataan menunjukkan angka lebih besar dari rtabel yaitu 0,2159 hal tersebut menunjukkan bahwa item promosi dinyatakan valid.

Uji Validitas Minat

\begin{tabular}{|c|c|c|c|}
\hline $\begin{array}{c}\text { Item } \\
\text { pernyataan }\end{array}$ & $r_{\text {hitung }}$ & $r_{\text {tabel }}$ & Keterangan \\
\hline minat_1 & 0,282 & \multirow{11}{*}{$\begin{array}{c}\text { Instrument } \\
\text { valid jika } \\
r_{\text {hitung }}>r_{\text {tabel }} \\
\text { dengan } \mathrm{df}= \\
\text { pada taraf } \\
\text { signifikan } 5 \% \\
\text { sehingga } \\
\text { diperoleh } r_{\text {tabel }}= \\
0,2159\end{array}$} & Valid \\
\hline minat_2 & 0,355 & & Valid \\
\hline minat_3 & 0,408 & & Valid \\
\hline minat_4 & 0,246 & & Valid \\
\hline minat_5 & 0,418 & & Valid \\
\hline minat_6 & 0,424 & & Valid \\
\hline minat_7 & 0,416 & & Valid \\
\hline minat_8 & 0,482 & & Valid \\
\hline minat_9 & 0,464 & & Valid \\
\hline minat_10 & 0,542 & & Valid \\
\hline minat_11 & 0,515 & & Valid \\
\hline
\end{tabular}

Sumber: Hasil Output SPSS Versi 23

Berdasarkan hasil uji validitas minat menabung di atas menunjukkan bahwa nilai rhitung dari masing-masing item pernyataan menunjukkan angka lebih besar dari rtabel yaitu 0,2159. Hal tersebut menunjukkan bahwa item minat menabung dinyatakan valid.

Uji Reliabilitas

\begin{tabular}{|c|c|c|}
\hline Variabel & $\begin{array}{c}\text { Cronbach's } \\
\text { alpha }\end{array}$ & $\begin{array}{c}\text { N of } \\
\text { Items }\end{array}$ \\
\hline Religiusitas & 0,733 & 11 \\
\hline
\end{tabular}

POINT Vol. 1, No. 2, Juli 2020

\begin{tabular}{|c|l|l|}
\hline Pelayanan & 0,724 & 11 \\
\hline Promosi & 0,309 & 11 \\
\hline $\begin{array}{c}\text { Minat } \\
\text { menabung }\end{array}$ & 0,497 & 11 \\
\hline
\end{tabular}

Sumber: Hasil Output SPSS Versi 23

Dari hasil output SPSS di atas menunjukkan bahwa Cronch's Alpha untuk variabel religiusitas $0,733>0,60$ dengan demikian variabel kepercayaan dapat dikatakan reliabel. Variabel pelayanan $0,724>0,60$, dengan demikian pelayanan dapat dikatakan reliabel. Variabel promosi 0,309 $<0,60$ sehingga variabel promosi dinyatakan tidak reliabel. Kemudian Cronch's Alpha untuk variabel minat $0,497<0,60$ sehingga variabel minat dinyatakan tidak reliabel.

\section{Analisis Deskriptif}

Descriptive Statistics

\begin{tabular}{|c|c|c|c|c|c|}
\hline & & Minimum & Maximum & Mean & Std. Deviation \\
\hline Religiusitas & 3 & 29 & 55 & 45,35 & 4,592 \\
\hline Pelayanan & 4 & 32 & 52 & 43,40 & 4,260 \\
\hline Promosi & 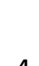 & 31 & 51 & 40,18 & 4,057 \\
\hline Minat & 4 & 29 & 55 & 42,85 & 4,392 \\
\hline Valid N (listwise) & 3 & & & & \\
\hline
\end{tabular}

Sumber: Hasil Output SPSS Versi 23

Berdasarkan hasil output SPSS diatas dapat dilihat pada variabel religiusitas dengan jumlah sampel 83 dengan nilai rata-rata sebesar 45,35 dan standar deviasinya 4,592 $(45,35>4,592)$. Nilai terendah adalah 29 dan nilai tertinggi adalah 55. Variabel pelayanan dengan jumlah sampel 84 dengan nilai rata-rata sebesar 43,40 dan standar deviasinya adalah 
$4,260(43>4,20)$. Nilai terendah adalah 32 dan nilai tertinggi adalah 52. Variabel promosi dengan jumlah sampel 84 dengan nilai rata-rata sebesar 40,18 dan standar deviasinya adalah $4,057(40,18>4,057)$. Nilai terendah adalah 31 dan nilai tertinggi adalah 51 . Variabel minat menabung dengan jumlah variabel 84 dengan nilai rata-rata sebesar 42,85 dan standar deviasinya adalah 4,392 (42,85>4,392). Nilai terendah adalah 29 dan nilai tertinggi adalah 55. Sehingga menunjukkan hasil yang normal.
Uji Asumsi Klasik
Uji Normalitas

One-Sample Kolmogorov-Smirnov Test

\begin{tabular}{|c|c|}
\hline & $\begin{array}{l}\text { Unstandardized } \\
\text { Residual }\end{array}$ \\
\hline 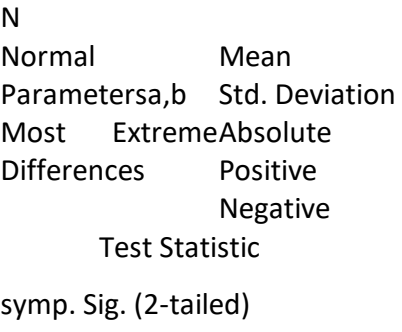 & $\begin{array}{l}83 \\
, 0000000 \\
3,73467023 \\
, 040 \\
040 \\
, 033 \\
-, 040 \\
\quad, 200 c, d\end{array}$ \\
\hline
\end{tabular}

a. Test distribution is Normal.

b. Calculated from data.

c. Lilliefors Significance Correction.

d. This is a lower bound of the true significance.

Sumber: Hasil Output SPSS Versi 23

Berdasarkan hasil output SPSS di atas dapat dilihat bahwa nilai Asymp.Sig (2-Tailed) adalah 0,200 sehingga lebih besar dari nilai signifikan $0,05(0,200>0,05)$. Maka dapat disimpulkan bahwa nilai residual tersebut bersifat normal, sehingga data dalam penelitian ini telah berdistribusi normal.Normalitas data merupakan syarat pokok yang harus dipenuhi ke dalam analisis statistic parametrik.Oleh karena itu, data berdistribusi normal maka analisis dapat dilanjutkan dengan statistik parametrik.

Uji Multikolinearitas

\begin{tabular}{|c|c|c|c|c|}
\hline \multirow{2}{*}{ Model } & \multicolumn{2}{|c|}{} & \multicolumn{2}{c|}{$\begin{array}{c}\text { Collinearity } \\
\text { Statistics }\end{array}$} \\
\cline { 2 - 5 } & $\mathrm{T}$ & Sig. & Tol & VIF \\
\hline (Constant) & 2,174 &, 033 & & \\
\hline Religiusitas & 1,819 &, 073 &, 774 & 1,291 \\
\hline Pelayanan & 2,065 &, 042 &, 693 & 1,443 \\
\hline Promosi & 2,563 &, 012 &, 847 & 1,181 \\
\hline (Constant) & 2,174 &, 033 & & \\
\hline
\end{tabular}

a. Dependent Variable: minat

\section{Sumber: Hasil Ooutput SPSS Versi 23}

Berdasarkan hasil output di atas dapat diketahui nilai tolerance dari variabel religiusitas adalah 0,774 >0,05. Variabel pelayanan adalah 0,693 $>0,05$. Kemudian variabel promosi adalah 0,847 >0,05. Dapat disimpulkan tidak terjadi multikolinearitas. Selanjutnya berdasarkan nilai VIF dari variabel religiusitas (X1) adalah 1,291 < 5 variabel pelayanan (X2) adalah 1,443 $<5$ dan variabel promosi (X3) adalah 1,181 < 5. Jadi, dapat disimpulkan bahwa nilai VIF dari ketiga variabel di atas lebih kecil dari 5 sehingga tidak terjadi multikolinearitas.

Uji Autokorelasi

Model Summaryb

\begin{tabular}{|c|c|c|c|c|c|}
\hline Model & $R$ & $R$ Square & $\begin{array}{c}\text { Adjusted R } \\
\text { Square }\end{array}$ & $\begin{array}{c}\text { Std. Error of } \\
\text { the Estimate }\end{array}$ & $\begin{array}{c}\text { Durbin- } \\
\text { Watson }\end{array}$ \\
\hline 1 &, $531 \mathrm{a}$ &, 282 &, 255 & 3,805 & 1,993 \\
\hline
\end{tabular}

a. Predictors: (Constant), promosi, religiusitas, pelayanan

b. Dependent Variable: minat

Sumber: Hasil Output SPSS Versi 23

Berdasarkan hasil dari uji autokorelasi di atas diketahui bahwa nilai Durbin Watson sebesar 1,993 dengan $n=84$ dan $k=3$ didapat nilai $\mathrm{DL}=1,560$ dan $\mathrm{DU}=1,715$ jadi nilai $4-\mathrm{DL}=$ 2,44 dan 4-DU=2,285. Sehingga dapat 
Norma Sari ${ }^{1}$, Budi GautamaSiregar ${ }^{2}$, Hamni Fadilah Nasution ${ }^{3}$, Damri Batubara 4

disimpulkan bahwa $(1,715<1,993<2,44)$ yang hasilnya tidak terjadi autokorelasi.

Uji Heteroskedastisitas

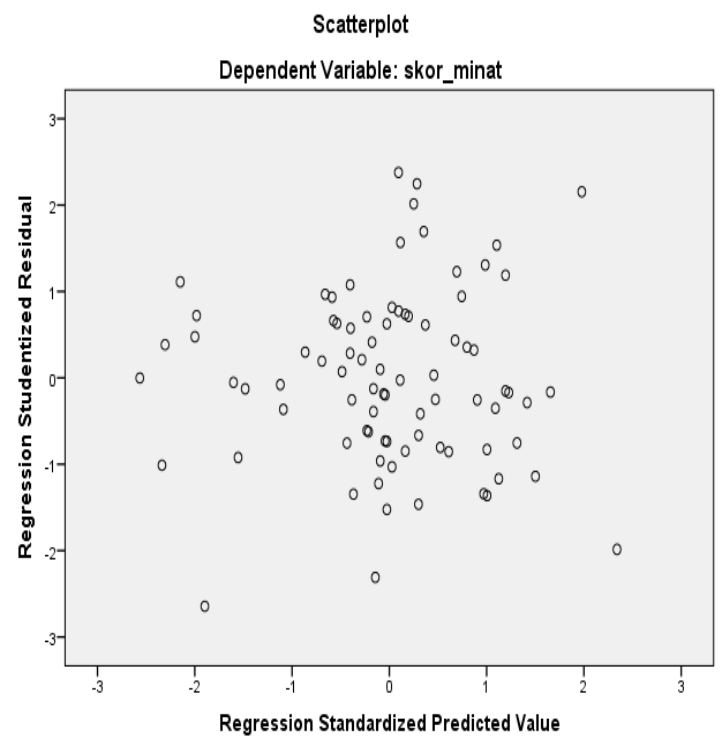

Sumber: Hasil Output SPSS Versi 23

Berdasarkan gambar di atas dapat dilihat bahwa titik-titik tidak membentuk suatu pola tertentu.Titik-titik menyebar di atas dan di bawah angka 0 di bawah sumbu $Y$, jadi dapat disimpulkan bahwa model regresi terbebas dari heteroskedastisitas.

Uji Koefisien Determinasi (R2)

Model Summary

\begin{tabular}{|l|l|l|l|l|}
\hline Model & $R$ & $\begin{array}{l}\text { R } \\
\text { Square }\end{array}$ & $\begin{array}{l}\text { Adjusted Rquare } \\
\text { Squar }\end{array}$ & $\begin{array}{l}\text { Std. Error of the } \\
\text { Estimate }\end{array}$ \\
\hline 1 & 531a & 282 &, 255 & 3,805 \\
\hline
\end{tabular}

a. Predictors: (Constant), promosi, religiusitas, pelayanan

Sumber: Hasil Output SPSS Versi 23

Berdasarkan hasil output SPSS di atas, dapat diketahui nilai koefisien determinasi ( $R$ Square) sebesar 0,282 adalah pengkuadratan dari koefisien korelasi atau R, yaitu $531 \times 531=$ 282. Besarnya angka koefisien determinasi ( $R$ Squre) sama dengan $28,2 \%$ angka koefisien determinasi ( $R$ Square) 0,282 dengan angka
POINT Vol. 1, No. 2, Juli 2020 tersebut mengandung arti bahwa religiusitas, pelayanan dan promosi terhadap minat menabung di bank syariah sebesar $28,2 \%$. Sedangkan sisanya $(100 \%-28,2 \%=71,8 \%)$ dipengaruhi oleh variabel lain diluar model regresi ini.

Analisis Regresi Linear Berganda Coefficientsa

\begin{tabular}{|c|c|c|c|c|c|}
\hline & \multicolumn{2}{|c|}{$\begin{array}{c}\text { Unstandardized } \\
\text { Coefficients }\end{array}$} & $\begin{array}{c}\text { Standardized } \\
\text { Coefficients }\end{array}$ & & \\
\cline { 2 - 4 } Model & $\mathrm{B}$ & Std. Error & Beta & $\mathrm{T}$ & Sig. \\
\hline (Constant) & 12,104 & 5,567 & & 2,174 &, 033 \\
Religiusitas &, 189 &, 104 &, 197 & 1,819 &, 073 \\
Pelayanan &, 244 &, 118 &, 237 & 2,065 &, 042 \\
Promosi &, 289 &, 113 &, 266 & 2,563 &, 012 \\
\hline
\end{tabular}

a. Dependent Variable: minat

Sumber: Hasil Output SPSS Versi 23

Berdasarkan tabel di atas dapat disimpulkan Unstandardized Coefficient tabel di atas maka persentase analisis regresi linier berganda dalam penelitian ini adalah:

$$
\mathrm{Y}=\alpha+\mathrm{b}_{1} \mathrm{X}_{1}+\mathrm{b}_{2} \mathrm{X}_{2}+\mathrm{b}_{3} \mathrm{X}_{3}
$$

Minat pedagang $=12,104+b 10,189+b 2$

$0,244+b 30,289+e$

Konstanta sebesar 12,104 , maka minat menabung pedagang sebesar 12,104 satuan.Nilai koefisien variabel religiusitas sebesar 0,189 menunjukkan bahwa apabila religiusitas mengalami penurunan sebesar 1 satuan maka minat menabung pedagang mengalami penurunan sebesar 0,189 satuan.Nilai koefisien variabel pelayanan sebesar 0,244 menunjukkan bahwa apabila pelayanan mengalami penurunan sebesar 1 satuan maka minat menabung pedagang mengalami penurunan sebesar 0,244 satuan. 
Nilai koefisien variabel promosi sebesar 0,289 menunjukkan bahwa apabila promosi mengalami penurunan sebesar 1 satuan maka minat menabung pedagang mengalami penurunan sebesar 0,189 satuan.

Uji Hipotesis

Uji Signifikansi Parsial (Uji t)

Untuk mengetahui pengaruh variabel bebas secara parsial terhadap minat menabung dilakukan uji t, hipotesis yang berbunyi:

$\mathrm{H} 1=$ ada pengaruh faktor religiusitas terhadap minat menabung pedagang di pasar baru panyabungan menabung di bank syariah.

$\mathrm{H} 2$ = ada pengaruh faktor pelayanan terhadap minat menabung pedagang di pasar baru panyabungan menabung di bank syariah.

$\mathrm{H} 3=$ ada pengaruh faktor promosi terhadap minat menabung pedagang di pasar baru panyabungan menabung di bank syariah.

Coefficientsa

\begin{tabular}{|c|c|c|}
\hline & & \\
Model & $\mathrm{T}$ & Sig. \\
\hline (Constant) & 2,174 &, 033 \\
Religiusitas & 1,819 &, 073 \\
Pelayanan & 2,065 &, 042 \\
Promosi & 2,563 &, 012 \\
\hline
\end{tabular}

a. Dependent Variable: minat

Sumber: Hasil Output SPSS Versi 23

Berdasarkan tabel di atas dapat diketahui bahwa thitung untuk variabel religiusitas (X11) adalah 1,819 dan untuk ttabel diperoleh dari rumus $d f=n-k-1$ atau $d f=84-3-1=80$ hasil yang diperoleh 1,990 sehingga $t_{\text {hitung }}>t_{\text {tabel }}(1,819<$ 1.990) maka H1 ditolak, jadi dapat disimpulkan bahwa dari hasil uji tidak terdapat pengaruh religiusitas terhadap minat menabung pedagang Pasar Baru Panyabungan di Bank Syariah Panyabungan.thitungvariabel pelayanan (X2) adalah 2,065 $t_{\text {hitung }}>t_{\text {tabel }}(2,065>1,990)$ maka $\mathrm{H} 2$ diterima. Kemudian thitung untuk variabel promosi (X3) adalah 2,563 sehingga $t_{\text {hitung }}>t_{\text {tabel }}(2,563>1,990)$ maka H3 diterima.

\section{Uji Simultan (Uji F)}

Untuk mengetahui pengaruh variabel bebas secara parsial terhadap minat menabung dilakukan uji F, hipotesis yang berbunyi:

H4 = ada pengaruh faktor religiusitas, pelayanan dan promosi secara bersama-sama terhadap minat menabung pedagang di pasar baru panyabungan menabung di bank syariah.

\section{ANOVAa}

\begin{tabular}{|l|c|c|c|c|}
\hline Model & $\mathrm{f}$ & Mean Square & $\mathrm{F}$ & Sig. \\
\hline Regression & & 149,693 & 10,340 &, $000 \mathrm{~b}$ \\
Residual & 9 & 14,477 & & \\
Total & 2 & & & \\
\hline
\end{tabular}

a. Dependent Variable: minat

b. Predictors: (Constant), promosi, religiusitas, pelayanan Sumber: Hasil Output SPSS Versi 23

Berdasarkan hasil uji output SPSS di atas bahwa nilai Fhitung sebesar 10,340 dan Ftabel sebesar 2,72 sehingga $F_{\text {hitung }}>F_{\text {tabel }}(10,340>$ 2,72), maka H4 diterima. Selanjutnya untuk nilai signifikan sebesar 0,000 sehingga nilai signifikan $<0,05(0,000<0,05)$ maka H4 diterima. Jadi dapat disimpulkan bahwa terdapat pengaruh religiusitas, pelayanan dan promosi terhadap minat menabung pedagang Pasar Baru Panyabungan menabung di Bank Syariah Panyabungan. 
Norma Sari ${ }^{1}$, Budi GautamaSiregar ${ }^{2}$, Hamni Fadilah Nasution ${ }^{3}$, Damri Batubara 4

\section{PENUTUP}

\section{Kesimpulan}

Berdasarkan hasil pembahasan, dapat disimpukan sebagai berikut:

1. Dari hasil perhitungan melalui SPSS versi 23, nilai Ftabel $\mathrm{df}=84-3-1=80$ pada probabilitas $5 \%$ diperoleh 2,72 dan dari $F_{\text {hitung }}$ sebesar 10,340 , ini menunjukkan bahwa $F_{\text {hitung }}>$ $F_{\text {tabel }}(10,340>2,72)$

2. Secara parsial akan digambarkan pengaruh antar variabel independen terhadap variabel dependen sebagai berikut:

a. Nilai thitung untuk variabel religiusitas adalah 1,819, ini menunjukkan bahwa $t_{\text {hitung }}<t_{\text {tabel }}(1,819<1,990)$ sehingga tidak terdapat pengaruh variabel religiusitas terhadap minat menabung atau $\mathrm{H} 1$ ditolak.

b. Nilai thitung untuk variabel pelayanan adalah 2,065, ini menunjukkan bahwa $t_{\text {hitung }}>t_{\text {tabel }} \quad(2,065>1,990) \quad$ sehingga terdapat pengaruh variabel pelayanan terhadap minat menabung atau $\mathrm{H} 2 \mathrm{di}$ terima.

c. Nilai thitung untuk variabel promosi adalah 2,563 ini menunjukkan bahwa thitung $>$ ttabel $(2,563>1,990)$ sehingga terdapat pengaruh yang signifikan antara variabel promosi terhadap minat menabung atau $\mathrm{H} 3$ diterima.

Berdasarkan uji t di atas, maka hipotesis yang terbukti berpengaruh signifikan terhadap minat menabung di bank syariah Panyabungan adalah variabel pelayanan
POINT Vol. 1, No. 2, Juli 2020 dan promosi secara parsial diterima akan tetapi variabel religiusitas hipotesisnya ditolak, dikarenakan masyarakat saat ini berpendapat bahwa bank syariah dan bank konvensional sama yang membedakan hanya nama produk saja. Dan variabel yang paling dominan adalah variabel promosi.

\section{Saran}

Semoga adanya peningkatan kinerja perbankan syariah ke depannya.

\section{DAFTAR PUSTAKA}

Abdurrahman Saleh Dan Muhib Abdul Wahab, Psikologi Suatu Pengantar Data Perspektif Islam, Jakarta: Kencana, 2004.

Adiwarman Karim, Bank Islam Analisis Fiqih dan Keuangan, Jakarta: IIIT Indonesia, 2003.

Departemen Pendidikan Nasional, Kamus Besar Bahasa Indonesia, Jakarta: PT. Gramedia Pustaka Utama, 2008.

Ikatan Bankir Indonesia, Mengelola Kualitas Layanan Perbankan, Jakarta: PT Gramedia Pustaka Utama, 2014.

Muhaimin, Paradigma Pendidikan Islam: Upaya Mengefektifkan Pendidikan Agama Sekolah, Bandung: PT. Mahasiswa Rodakarya, 2002.

Muhammad Isa, dkk, Manajemen Pemasaran Bank.

Wawancara Dengan Pengurus Pasar Baru Panyabungan. 
